\title{
Antiproliferative Activity of CCN3: Involvement of the C-Terminal Module and Post-Translational Regulation
}

\author{
A.M. Bleau, ${ }^{1}$ N. Planque, ${ }^{1}$ N. Lazar, ${ }^{1}$ D. Zambelli, ${ }^{2}$ A. Ori, ${ }^{1,2}$ T. Quan, ${ }^{3}$ G. Fisher, ${ }^{3}$ K. Scotlandi, ${ }^{2}$ \\ and B. Perbal ${ }^{1}$ * \\ ${ }^{1}$ Université Paris7-D. Diderot, UFR de Biochimie, Laboratoire d'Oncologie Virale et Moléculaire, \\ 2 place Jussieu, 75005 Paris, France \\ ${ }^{2}$ Laboratorio di Ricerca Oncologica, Istituti Ortopedici Rizzoli, Via Di Barbiano 1/10, 40136 Bologna, Italy \\ ${ }^{3}$ Department of Dermatology, University of Michigan Medical School, 1150 W. Medical Center Dr., \\ Medical Science I, Room 6447, Ann Arbor, Michigan 48109-0609
}

\begin{abstract}
Previous work had suggested that recombinant CCN3 was partially inhibiting cell proliferation. Here we show that native CCN3 protein secreted into the conditioned medium of glioma transfected cells indeed induces a reduction in cell proliferation. Large amounts of CCN3 are shown to accumulate both cytoplasmically and extracellularly as cells reach high density, therefore highlighting new aspects on how cell growth may be regulated by $\mathrm{CCN}$ proteins. Evidence is presented establishing that the amount of CCN3 secreted into cell culture medium is regulated by posttranslational proteolysis. As a consequence, the production of $\mathrm{CCN} 3$ varies throughout the cell cycle and CCN3 accumulates at the G2/M transition of the cycle. We also show that CCN3-induced inhibition of cell growth can be partially reversed by specific antibodies raised against a C-terminal peptide of CCN3. The use of several clones expressing various portions of $\mathrm{CCN} 3$ established that the $\mathrm{CT}$ module of $\mathrm{CCN} 3$ is sufficient to induce cell growth inhibition. J. Cell. Biochem. 101: 1475-1491, 2007. () 2007 Wiley-Liss, Inc.
\end{abstract}

Key words: $\mathrm{CCN} 3$; NOV; CCN; cell growth inhibition; cell cycle; proteasome

The CCN proteins constitute a new family of secreted matricellular cell growth and differentiation regulators [Lau and Lam, 1999; Perbal, 2001, 2003, 2004; Brigstock, 2003; Planque and Perbal, 2003; Perbal and Takigawa, 2005; Rachfal and Brigstock, 2005]. Their biological properties are diverse and rely on interactions with multiple targets localized in different sub-cellular compartments. CCN proteins interact with receptors, matrix proteins, ion channels, as well as cytosolic and

A.M. Bleau and N. Planque contributed equally to this work.

Grant sponsor: European commission; Grant number: PROTHETS LSHC-CT-2004-5030306; Grant sponsor: French Ministry of Education and Research.

*Correspondence to: Prof. B. Perbal, Université Paris7-D. Diderot, UFR de Biochimie, Laboratoire d'Oncologie Virale et Moléculaire, 2 place Jussieu, Case 7048, 75005 Paris, France. E-mail: perbal@ccr.jussieu.fr

Received 31 October 2006; Accepted 13 December 2006 DOI 10.1002/jcb.21262

(c) 2007 Wiley-Liss, Inc. nuclear proteins. This led to the proposal that CCN proteins act as scaffolding proteins permitting the coordination and functional interconnection of various signaling pathways involved in the regulation of cell proliferation, differentiation, and death [Perbal, 2001, 2003; Lombet et al., 2003; Bleau et al., 2005; Planque, 2006].

The variety of functions attributed to the CCN proteins stem from their conserved tetramodular organization with structural modules showing partial identity with four classes of proteins known to play critical roles in fundamental signaling and/or regulatory pathways. Indeed, the first constitutive module resembles IGFBPs, the second shares identity with Von Willebrand protein, the third with thrombospondin (TSP1), and the fourth module contains a cystine knot that allows dimerization of various growth factors and matricellular proteins [Bork, 1993; Perbal and Planque, 2006].

Very little is known regarding the biochemical activities of the CCN proteins endowed with biological properties that are dependent upon cell origin and developmental state [Planque 
and Perbal, 2003; Perbal and Takigawa, 2005]. Studies performed with CCN3 indicated that inhibition of cell proliferation was a common theme in both normal and tumor cells of various types [Joliot et al., 1992; Gupta et al., 2001; Fu et al., 2004; Gellhaus et al., 2004; Benini et al., 2005; Fukunaga-Kalabis et al., 2006; McCallum et al., 2006]. In all systems thus far tested cells that produced CCN3 were themselves responsive to its antiproliferative effects, therefore suggesting an autocrine type of response.

In order to decipher the mechanisms by which cells proliferate in spite of CCN3 anti-proliferative properties, we determined the effects of this protein on cell growth concentrating on the relationships between degree of CCN3-induced inhibition and amounts of CCN3 protein secreted during different stages of cell growth, as well as the various phases of the cell cycle. Our results indicated that the antiproliferative activity of CCN3 is modulated by a posttranslational control of the amount of protein produced per cell during growth. We also identified the C-terminal module of CCN3 as sufficient to produce the growth inhibitory effects. This observation reemphasizes the critical role of this module and points to the interactions driven by this module as essential for the biological activity of CCN3.

\section{MATERIALS AND METHODS}

\section{Construction of Expression Vectors}

The pcDNA-CCN3 vectors were obtained by cloning PCR-amplified CCN3 sequences from the pCMV82 (nucleotide 1-1,943 of human CCN3 inserted at the EcoRI site of $\mathrm{pCB} 6$ vector) between the EcoRI sites of pcDNA6/V5-His A vector (Invitrogen) for the pCMV47 construct (nucleotide 1-1,143) [Benini et al., 2005], and between the EcoRI and XbaI sites for the PNH35 and PNH45 constructs [Planque et al., 2006]. For PNH35 and PNH45, the signal peptide of CCN3 was PCR-amplified, inserted in the EcoRI site of a Bluescript derived vector $(\mathrm{BBg})$, sequenced, and then inserted at the EcoRI site of the pcDNA-CCN3 constructs. All constructs were sequenced. Figure 1 outlines the constructs and nomenclature used in this study.

The sequences encoding each exon of human CCN3 were cloned at the EcoRI and SalI sites of pTEF-MF yeast expression vector (DualsystemsBiotech). The recipient pTEFMF was modified at its EcoRI/HindIII sites by ligating a double-strand oligonucleotide (5'-AATTGGGATCCCATCACCATCACCATCACGAATTCA-3') in order to add a carboxy-6 Histidine (6HIS) tag in the recombinant proteins. Recombinant proteins are secreted in the yeast culture medium.

\section{Cell Lines and Establishment of Stable Clones}

The glioblastoma cell line (G59) was originally isolated and provided by Dr. M. Westphal, and has been described previously [Li et al., 1996]. The G540 cells expressing human CCN3 were stably transfected by means of the pCMVCCN3 plasmid (pCMV82) and G418 selection. G59 cells were also transfected with either pCMV-CCN3 (pCMV47), PNH35, PNH45, or pcDNA DNA. Cell transfections were performed for $48 \mathrm{~h}$ in $3.5 \mathrm{~cm}$ dishes in $3 \mathrm{ml}$ of completed medium. For each dish, $2 \mu \mathrm{g}$ of DNA were incubated with $6 \mu$ l of EXGEN500 (Euromedex) in a final volume of $100 \mu \mathrm{l}$ for $15 \mathrm{~min}$ at room

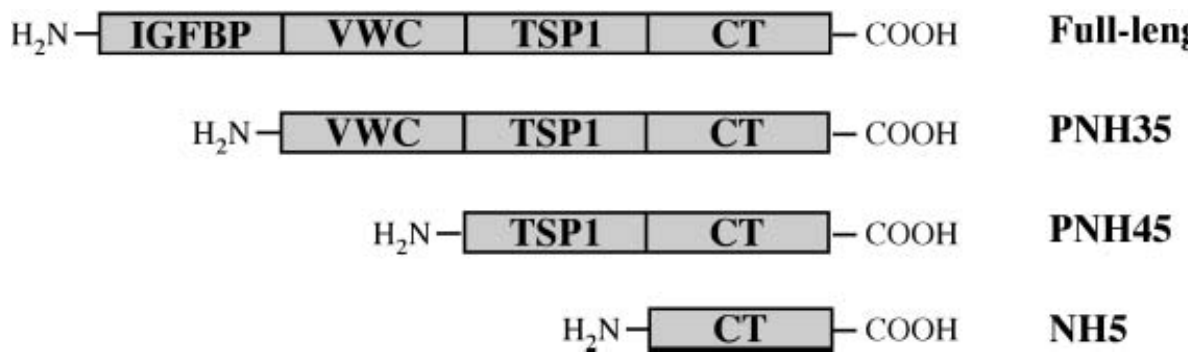

Fig. 1. Schematic diagram depicting the modular organization of the $\mathrm{CCN} 3$ protein and the nomenclature used in this study. First three lines: CCN3 constructs used for the establishment of stable cell lines: full-length CCN3 (expressed in pCMV82 and pCMV47); $\mathrm{PNH} 35$ lacks the first amino-terminal module (IGFBP); PNH45 lacks both IGFBP and VWC modules. In addition, to produce and purify recombinant CCN3 proteins, the full-length CCN3 cDNA and the exon encoding the CT module (NH5) have been inserted in the bacterial pGEX-4T1 vector (producing GST-CCN3 and GST-NH5 proteins respectively) [Li et al., 2002], and NH5 in yeast pTEF-MEF vector. 
temperature, according to the manufacturer's instructions. Forty-eight hours after transfection, cells were seeded in $10 \mathrm{~cm}$ dishes and selected by addition of $5 \mu \mathrm{g} / \mathrm{ml}$ of Blasticidin (Invitrogen) for about 12 days. Individual clones were picked up and tested for expression of the CCN3 protein by Western blot analysis.

Cells were grown in Dulbecco's Modified Eagle's Medium (DMEM) (Sigma) supplemented with $10 \%$ fetal calf serum (FCS) (Sigma) and L-Glutamine-Penicillin-Streptomycin solution (Sigma) (complete medium). All cells were maintained at $37^{\circ} \mathrm{C}$ in $5 \% \mathrm{CO}_{2}$.

\section{Production and Purification of Recombinant Proteins}

To produce recombinant CCN3 proteins, the full-length CCN3 cDNA and the exon encoding the CT module (NH5) have previously been inserted in the pGEX-4T1 vector (AmershamGE Healthcare) [Li et al., 2002], producing gluthatione-S-transferase fusion proteins (GST-CCN3 and GST-NH5, respectively).

Overnight precultures were diluted 100 times in LB Broth (Lennox) medium containing $100 \mu \mathrm{g} / \mathrm{ml} \mathrm{Ampicillin} \mathrm{(Sigma)} \mathrm{and} \mathrm{grown} \mathrm{at}$ $37^{\circ} \mathrm{C}$ until $\mathrm{OD}_{600 \mathrm{~nm}}$ reached $0.7-0.9$. Induction of expression of the recombinant proteins was performed by incubation in the presence of $0.1 \mathrm{mM}$ IPTG for $2.5 \mathrm{~h}$. After centrifugation, pellets were resuspended in $50 \mathrm{mM}$ Tris $\mathrm{pH}$ 8.0; $1 \mathrm{mM}$ EDTA; $100 \mathrm{mM} \mathrm{NaCl}$ and proteinases inhibitors: Complete Mini Tablets (Roche), $100 \mu \mathrm{M}$ phenylmethylsulphonylfluoride (PMSF), $100 \mu \mathrm{M} N$-Tosyl-L-Lysine chloromethyl ketone (TLCK), $1 \mathrm{mM}$ benzamidine, $100 \mu \mathrm{M} N$-TosylPhenylalanine chloromethyl ketone (TPCK), and $300 \mu \mathrm{g} / \mathrm{ml}$ lysozyme was added and lysis was performed for $20 \mathrm{~min}$ on ice. After the addition of $1 \%$ Triton X-100, lysates were sonicated on ice. After centrifugation, supernatants were incubated with Glutathione Sepharose $^{\mathrm{TM}} 4$ Fast Flow beads (AmershamGE Healthcare) in phosphate-buffered saline (PBS) for $1 \mathrm{~h}$ at $4{ }^{\circ} \mathrm{C}$ on a rotating wheel. For GST-CCN3, PBS was complemented with $5 \%$ non-fat milk and $0.5 \mathrm{mM}$ ATP. Beads were then washed several times with PBS-proteinases inhibitors. Recombinant proteins were recovered by three elutions of $1 \mathrm{~h}$ on ice with a solution containing $20 \mathrm{mM}$ glutathione, $100 \mathrm{mM}$

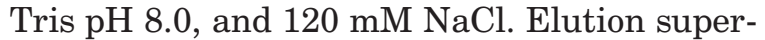
natants were pooled.
GST-NH5 recombinant proteins were then cleaved by thrombin and subsequently purified by immuno-affinity chromatography. To that purpose, GST-NH5 proteins were incubated in PBS containing $10 \mathrm{U}$ of thrombin (Sigma) overnight at $37^{\circ} \mathrm{C}$ with weak agitation, then purified by two successive affinity chromatography on anti-GST and anti-NH5 Sepharose columns. NH5 proteins were eluted with $100 \mathrm{mM}$ glycine buffer $\mathrm{pH} 2.8$ and collected into test tubes containing $100 \mu \mathrm{l} 1 \mathrm{M}$ Tris buffer $\mathrm{pH}$ 8.0.

For the production of recombinant CCN3 modules in yeast, DSY-S yeasts were treated with polyethylene glycol and lithium acetate (PEG/LiOAc master mix) and transformed with $100 \mathrm{ng}$ of each pTEF-MF recombinant vectors according to the manufacturer's instructions (DualsystemsBiotech). Yeasts were grown in appropriate selective medium (-URA). Nontagged recombinant $\mathrm{NH} 5$ proteins were purified from yeast culture medium by immuno-affinity chromatography (see below). 6HIS-tagged constructs were purified using nickel columns according to the manufacturer's instructions (Invitrogen). Proteins were eluted with $500 \mathrm{mM}$ imidazol.

All recombinant proteins were dialyzed overnight at $4^{\circ} \mathrm{C}$ against $10 \mathrm{mM} \mathrm{NH} \mathrm{NHCO}_{3}$, and lyophilized. Proteins were dissolved in PBS. Quantification was performed after SDSPAGE followed by Coomassie blue or silver staining of the gels.

\section{Antibodies Production and Purification}

The K19M antibody raised against CCN3 [Chevalier et al., 1998] was affinity purified from the immunized rabbit serum by affinity chromatography on Protein A Sepharose beads [Kyurkchiev et al., 2004]. Briefly, $1 \mathrm{ml}$ of nProtein A Sepharose ${ }^{\mathrm{TM}} 4$ Fast Flow (Amersham-GE Healthcare) was equilibrated with 20 $\mathrm{mM}$ Tris $\mathrm{pH}$ 8.0. An aliquot of $3 \mathrm{ml}$ of K19M antiCCN3 serum was loaded on the protein A column and then washed with $20 \mathrm{mM}$ Tris $\mathrm{pH}$ 8.0 and $20 \mathrm{mM}$ glycine $\mathrm{pH}$ 5.0. Antibody was eluted using $100 \mathrm{mM}$ glycine $\mathrm{pH} 2.5$ and neutralized with $1 \mathrm{M}$ Tris $\mathrm{pH}$ 8.0. Four fractions were pooled and concentrated on Vivaspin concentrator (Vivascience) to reach a final IgG concentration of $11 \mathrm{mg} / \mathrm{ml}$.

The GST-NH5 protein was also used as antigen to immunize rabbits (Agrobio). IgGs were purified from antisera using protein $\mathrm{A}$ 
column chromatography. For affinity purification, antisera were passed through a GST column to remove antibodies against GST. Purified rabbit sera were tested for their reactivity against recombinant CCN3 proteins produced in yeast and mammalian cells (Lazar et al., unpublished work).

The anti-NH5 antibody was coupled to $\mathrm{CNBr}$ activated Sepharose ${ }^{\mathrm{TM}}$ 4B (Amersham-GE Healthcare) following the protocol recommended by the manufacturer. Briefly, $20 \mathrm{mg}$ of antibodies were dissolved and dialyzed against $100 \mathrm{mM} \mathrm{NaHCO}{ }_{3} \mathrm{pH} 8.3$ containing $500 \mathrm{mM}$ $\mathrm{NaCl}$ (coupling buffer) and added to $3.5 \mathrm{ml}$ $\mathrm{CNBr}$-Sepharose swollen gel and the mixture was rotated end-over-end for $2 \mathrm{~h}$ at room temperature. Excess ligand was eluted with $20 \mathrm{ml}$ of coupling buffer and the gel was incubated in $100 \mathrm{mM}$ Tris- $\mathrm{HCl}$ buffer $\mathrm{pH} 8.0$ for $2 \mathrm{~h}$ at room temperature. The gel was washed five times in cycles consisting of $20 \mathrm{ml}$ of $100 \mathrm{mM}$ acetate buffer $\mathrm{pH} 4.0$ followed by $20 \mathrm{ml}$ of $100 \mathrm{mM}$ Tris-HCl buffer $\mathrm{pH}$ 8.0, each containing $500 \mathrm{mM} \mathrm{NaCl}$, and then packed into a PD10 column (Amersham-GE Healthcare).

\section{Growth Curve of Stable Clones}

Growth curves were performed by plating $2 \times 10^{4}$ G59 and G540 cells in 6 -well plates, attached cells were counted with a hemocytometer at the indicated times $(48 \mathrm{~h}, 72 \mathrm{~h}, 6,10$, 13,14 , and 16 days). Medium was changed daily to maintain cells for prolonged growth studies. For counting, attached cells were trypsinized and resuspended in DMEM $(200 \mu \mathrm{l}$ to $1.5 \mathrm{ml}$ depending on incubation time). Cell viability was evaluated by staining with $0.1 \%$ trypan blue. Cellular extracts were prepared and supernatants collected at each time point of the growth curve for Western blot analysis. Amounts of supernatant were normalized for the number of cells so as to establish the level of secretion per cell.

\section{Antiproliferative Effects of Recombinant CCN3 Proteins}

G59 cells $\left(5 \times 10^{3}\right)$ were seeded in 24-well plates in $500 \mu \mathrm{l}$ of complete medium. GST-CCN3 fusion protein (GST-CCN3) $(0.1 \mu \mathrm{M})$, GST-CT module (GST-NH5), and control GST was added $20 \mathrm{~h}$ after seeding. Alternate sources of recombinant CCN3-CT module were also used: $0.01 \mu \mathrm{M}$ of NH5 previously released from GST fusion by thrombin-cleavage (Thr-NH5) and
NH5 produced in yeast (Yeast-NH5). Cells were counted after 5 and 7 days of incubation.

\section{Conditioned Medium and Neutralization Experiments}

To study the effect of conditioned medium on exponentially growing cells, supernatants of cell cultures were collected at two different times (240 and $312 \mathrm{~h}$ ) and centrifuged at 1,200 rpm for $10 \mathrm{~min}$ to remove cell debris and detached cells. After dialysis against DMEM and filtration through $0.22 \mu \mathrm{m}$ filters (MILLEXGV, Millipore), the media were supplemented with FCS. G59 and G540 cells were seeded at $2 \times 10^{4}$ cells in 24 -well plates and incubated with the purified conditioned medium.

Neutralization experiments were performed by plating $5 \times 10^{3}$ G540 cells with addition of $500 \mu \mathrm{g} / \mathrm{ml}$ of the purified K19M antibody or $500 \mu \mathrm{g} / \mathrm{ml}$ of a purified anti-glycated bovine serumalbumine (BSA) produced in rabbit as control. Cells were counted after 5 days of incubation. With purified conditioned media, neutralizing experiments were performed by plating $2 \times 10^{4}$ cells in 24 -well plates and incubating them for 2 days with $500 \mu \mathrm{g} / \mathrm{ml}$ of purified K19M antibody.

\section{Flow Cytometry}

For the analysis of cell cycle distribution, adherent and floating cells were combined and washed in cold PBS. Cells were permeabilized in $1 \%$ paraformaldehyde-PBS for $5 \mathrm{~min}$ on ice, washed in PBS, fixed in 70\% ethanol and kept at $-20^{\circ} \mathrm{C}$ for $30 \mathrm{~min}$ or until analysis. Cells were rehydrated in PBS for $10 \mathrm{~min}$, washed with PBS, treated with RNase A (500 $\mu \mathrm{g} / \mathrm{ml})$ (Qiagen) and stained with propidium iodide $(50 \mu \mathrm{g} / \mathrm{ml})$. For analysis of integrin $-\alpha_{\mathrm{v}} \beta_{3}$ expression, cells were washed with cold BSA containing $2 \%$ FCS and incubated for $45 \mathrm{~min}$ on ice with $5 \mu \mathrm{g} / \mathrm{ml}$ of anti-integrin $\alpha_{\mathrm{v}} \beta_{3}$ antibody (Mouse monoclonal CD51, clone P2W7, Sigma). Cells were washed with PBS and then incubated with anti-mouse antibody coupled to AlexaFluor 488 (Molecular Probe) (dilution 1:200) for $30 \mathrm{~min}$ on ice. In all cases, a total of 10,000 events were acquired for each sample and analyzed on a standard fluorescence-activated cell sorting (FACS) calibur flow cytometer (BD Biosciences). Propidium iodide and AlexaFluor 488 fluorescence were measured by log amplification into the FL3 channel. 


\section{Proteasome Inhibition and Synchronization of Cells}

For proteasome inhibition, G540 cells were treated with $10 \mu \mathrm{M}$ MG132 (Z-Leu-Leu-Leu-al) (Sigma), $100 \mu \mathrm{M}$ LLnL (Calpain Inhibitor I) (Sigma) or dimethylsulfoxide (DMSO) for 6 or $24 \mathrm{~h}$.

For synchronization, G540 cells were arrested at (1) G0 phase by serum starvation for $48 \mathrm{~h}$, (2) in early $\mathrm{G} 1$ phase after refeeding for $6 \mathrm{~h}$ with complete medium, (3) in late G1 phase after refeeding for $24 \mathrm{~h}$ with medium containing $200 \mu \mathrm{M}$ mimosin (Sigma), (4) in G1/S phase after refeeding for $24 \mathrm{~h}$ with medium containing $2 \mu \mathrm{g} /$ $\mathrm{ml}$ of aphidicolin (Sigma), (5) in S phase by washing off aphidicolin for $5 \mathrm{~h}$, and (6) in the G2/ $\mathrm{M}$ phase $30 \mathrm{~h}$ after refeeding with medium containing $0.1 \mu \mathrm{g} / \mathrm{ml}$ of nocodazole (Sigma). Kinetic analysis of cell cycle distribution was performed by plating G59 and G540 cells in the exponential phase of growth. Cells were serum starved for $48 \mathrm{~h}$ and arrested in G1/S phase by a $24 \mathrm{~h}$ of incubation with $2 \mu \mathrm{g} / \mathrm{ml}$ of aphidicolin. Cells were released to the next phase by washing off aphidicolin. The distribution of cells in the various phases of the cell cycle was determined by FACS analysis at 6, 9, 12, and $24 \mathrm{~h}$.

\section{Quantitative Real-Time RT-PCR (qRT-PCR)}

Total RNAs were extracted from cultured human skin fibroblasts, and mRNAs levels were quantified by real-time RT-PCR as previously described [Quan et al., 2005]. Briefly, total RNA (100 ng) was reverse transcribed, with random primers, using Taqman Reverse Transcription Kit (Applied Biosystems). Real-time PCR was performed on a 7700 Sequence Detector (Applied Biosystems) using one-tenth of the reverse transcription reaction and Taqman Universal PCR Master Mix Reagents (Applied Biosystems). PCR primers and probes were from Applied Biosystems custom oligonucleotide synthesis service. Primers and FAMlabeled probe for CCN3 qRT-PCR were as follows: CCN3 sense primer, 5'-CCGCTGTCAGCTGGATGTG-3'; CCN3 anti-sense primer, 5'-AGAAAAGTTGAGGTGCCTGGAG-3'; CCN3 probe, 5'-ACTGCCTGAGCCTAACTGCCCAGCT-3'. Primers and VIC-labeled probe for 36B4 were described previously [Quan et al., 2005]. Multiplex PCR reactions contained primers and probes for CCN3 and 36B4. CCN3
mRNA levels were quantified based on standard curves. For comparison among treatment groups, CCN3 levels were normalized to the housekeeping gene 36B4 (a ribosomal protein used as an internal control for quantification) levels as an internal control.

Expression of MCM3 and MCM6 mRNAs was monitored by qRT-PCR performed on G59 parental and transfected cells. Briefly, $1 \mu \mathrm{g}$ of total RNA was denatured at $65^{\circ} \mathrm{C}$ for $10 \mathrm{~min}$ and then reverse-transcribed in a $50 \mu \mathrm{l}$ mixture containing $1.25 \mathrm{U} / \mu \mathrm{l}$ MultiScribe Reverse Transcriptase (Applied Biosystems), $0.4 \mathrm{U} / \mu \mathrm{l}$ of RNase inhibitor (Applied Biosystems), 1× TaqMan reverse transcriptase buffer, $5.5 \mathrm{mM}$ $\mathrm{MgCl}_{2}, 2.5 \mu \mathrm{M}$ Oligo(dT) and $500 \mu \mathrm{M}$ of each $\mathrm{dNTP}$ at $48^{\circ} \mathrm{C}$ for $40 \mathrm{~min}$. Primers were as follows: MCM3 sense primer, 5'-TACCGGCTGATTGTCAATGTGA-3'; MCM3 anti-sense primer, 5'-CAACCAGCTCCTCAAA-GGCA-3'; MCM6 sense primer, 5'-CCTTACCTGTGTCGGGCCTT-3'; MCM6 anti-sense primer, 5'-GCAGGTCTTGGAATGCAACA-3'. Glyceraldehyde-3-phosphate dehydrogenase (GAPDH) primers and probe as follows: GAPDH sense primer, 5'-GAAGGTGAAGGTCGGAGTC-3'; G-APDH anti-sense primer, 5'-GAAGATGGTGATGGGATTTC-3'; GAPDH probe: FAM-GAA 5'-GCTTCCCGTTCTCAGCC-3' Amplification was performed using $5 \mathrm{ng}$ of cDNA and 200-800 nM primers. GAPDH was quantified using TaqMan Universal PCR Master Mix (Applied Biosystems) while the other genes used a SYBR Green PCR Master Mix (Applied Biosystems). All PCR reactions were performed by using ABI PRISM 7900 Sequence Detection System (Applied Biosystems). The target genes mRNAs were quantified by measuring threshold cycles $\left(\mathrm{C}_{\mathrm{T}}\right)$ to determine the relative expression. Data were normalized to GAPDH. The relative expression of the different mRNAs was also normalized to a calibrator, consisting of the parental cell line mRNA, and was expressed as $2^{-\Delta \Delta \mathrm{CT}}$, where $\Delta \mathrm{C}_{\mathrm{T}}$ is $\mathrm{C}_{\mathrm{T}}$ target genes- $\mathrm{C}_{\mathrm{T}} \mathrm{GAPDH}$, and $\Delta \Delta \mathrm{C}_{\mathrm{T}}$ is $\Delta \mathrm{C}_{\mathrm{T}}$ sample$\Delta \mathrm{C}_{\mathrm{T}}$ calibrator.

\section{cDNA Microarray Hybridization and Analysis}

Hybridizations were performed on Human 1A (V2) Oligo microarray slides (Agilent Technologies) containing 18,716 oligo probes (60-mer length). Total RNAs were used to obtain labeled cRNAs, according to the manufacturer's instructions (Low RNA Input Fluorescent 
Linear Amplification Kit-Agilent Technologies). The G59 derived cell lines cRNAs were labeled with Cyanine 5-CTP (Cy5) (Perkin Elmer), while G59 was labeled with Cyanine 3-CTP (Cy3). In brief, $5 \mu \mathrm{g}$ of total RNAs were reversetranscribed with a T7 promoter primer using Moloney murine leukemia virus reverse transcriptase (Agilent Low RNA Input Fluorescent Linear Amplification Kit-Agilent Technologies). Next, cRNAs were synthesized from the doublestranded cDNAs using T7 RNA polymerase, which simultaneously incorporates Cy3 or Cy5. Labeled cRNAs were purified with RNeasy Mini Protocol for RNA Cleanup (Qiagen). After purification, $\mathrm{Cy} 3$ and $\mathrm{Cy} 5$ labeled cRNAs were fragmented by $25 \times$ fragmentation buffer at $60^{\circ} \mathrm{C}$ in water bath for $30 \mathrm{~min}$ and hybridized to microarray slides at $60^{\circ} \mathrm{C}$ for $17 \mathrm{~h}$ according to the manufacturer's instructions. The slides were washed with $6 \times$ sodium chloride-sodium phosphate-EDTA (SSPE) $+0.005 \%$ N-Lauroylsarcosine for $1 \mathrm{~min}$, with $0.06 \times \mathrm{SSPE}+0.005 \%$ $\mathrm{N}$-Lauroylsarcosine for $1 \mathrm{~min}$ and with drying solution (Agilent Technologies) for $30 \mathrm{~s}$.

Hybridized slides were scanned using GenePix 4000B microarray scanner (Axon Instruments) that acquires data at two wavelengths simultaneously (532 and $635 \mathrm{~nm}$ ). Image analysis and signal intensity for both channels were calculated by GenePix 3.0 (Axon Instruments). Spots showing evident blemishes were flagged and excluded from analysis. For each array NorTT.exe software (MRC System Toxicology Group, University of Leicester) normalizes gene expression data and performs statistical Student's $t$-test on each gene. Ratios between mean net fluorescence from $\mathrm{Cy} 5$ channel and mean net fluorescence from $\mathrm{Cy} 3$ channel were calculated for each spot (representing ratios between RNA expression values detected in either G59 transfectant cells and those obtained in the parental G59 cell line). Cy5:Cy3 expression ratios were log-transformed (base 2). Functional cluster result analysis was also performed by using the FatigoPlus program (Centro de Investigación Príncipe Felipe, Valencia, Spain).

\section{Gel Electrophoresis and Western Blotting}

To prepare proteins for immunoblotting, cells were lysed in NP40 buffer $(50 \mathrm{mM}$ Tris- $\mathrm{HCl}$ $\mathrm{pH}$ 8.0, $150 \mathrm{mM} \mathrm{NaCl}, 5 \mathrm{mM}$ EDTA, and $2 \%$ Noniped P40) with protease inhibitors (Complete Mini Tablets, Roche) and phosphatase inhibitors (50 $\mathrm{mM}$ sodium fluoride, $2 \mathrm{mM}$ sodium orthovanadate) for $30 \mathrm{~min}$ at $4^{\circ} \mathrm{C}$. After centrifugation at $15,000 \mathrm{~g}$, extracts were stored at $-80^{\circ} \mathrm{C}$ until use. Conditioned medium and cellular extracts $(30 \mu \mathrm{g})$ were resuspended in Laemmli buffer containing 2-mercaptoethanol, boiled for $10 \mathrm{~min}$ and subjected to electrophoresis under reducing conditions in $12.5 \%$ polyacrylamide gels. Separated proteins were subsequently transferred to nitrocellulose (Hybond-C Extra, Amersham-GE Healthcare) by a semi-dry blotter (LKB Biotech) as recommended by the supplier. The nitrocellulose sheet was blocked by incubation for $1 \mathrm{~h}$ at room temperature with 5\% non-fat milk in PBS- $0.2 \%$ Tween-20 (PBST) (blocking solution: PBSTmilk). The membrane was then incubated in blocking solution with either the purified antiK19M IgG (dilution 1/2,500) for CCN3 expression, anti-p21 (dilution 1/1,000) (Santa Cruz), anti-cytochrome C (Santa Cruz) (dilution $1 / 500$ ), anti- $\beta$-actin (dilution 1/1,000) (Sigma), and then extensively washed in PBST. The blots were further incubated in goat anti-rabbit or anti-mouse IgG conjugated with horseradish peroxidase (dilution 1/10,000) (Sigma) in blocking solution for $1 \mathrm{~h}$ at room temperature. The membranes were developed using the SuperSignal West Pico Chemiluminescent substrate from Pierce.

\section{Statistical Analysis}

Differences between two means were analyzed by Student's $t$-test and between treatment groups using one-way analysis of variance (ANOVA). Differences during the growth curve were compared by $t$-test with Bonferroni correction.

\section{RESULTS}

\section{Secreted CCN3 is Responsible for Inhibition of Cell Proliferation}

Previous results established that human G59 glioma cells expressing CCN3 (G540) grow at a slower rate than the parental G59 cells that do not express detectable levels of CCN3 [Gupta et al., 2001]. By growing these two cell types over extended periods of time, we established that the reduction of proliferation rate associated to CCN3 expression increased with time of culture and that G540 cells reached lower saturation density $(P<0.05)$ than $\mathrm{G} 59$ cells (Fig. 2). Reduction in proliferative rate was 


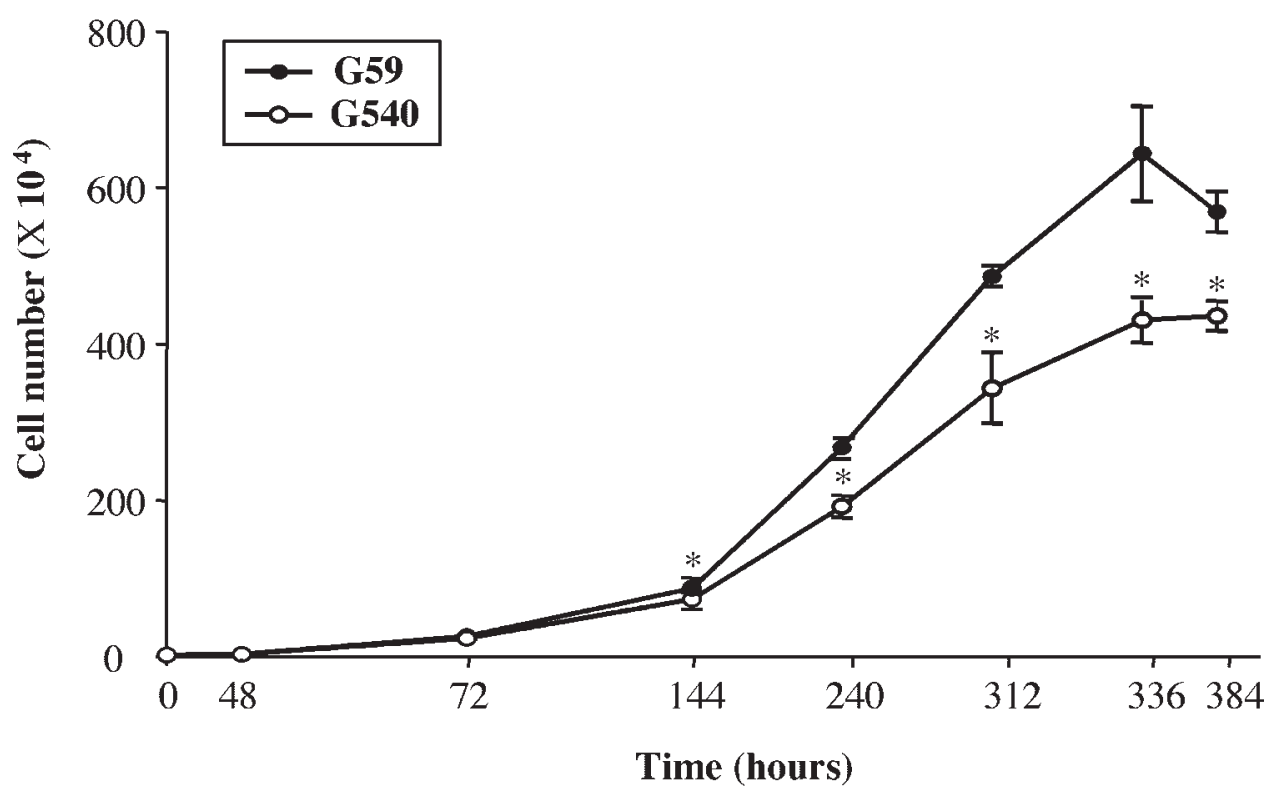

Fig. 2. CCN3 expression reduces cell proliferation in glioblastoma cells. In vitro growth curves of G59 and G540 glioma cell lines. For the in vitro proliferation assay, $2 \times 10^{4}$ cells from both the G59 and G540 cell lines were plated in 6-well plates and the cells were counted at the indicated time points (24-336 h). Results are for one representative experiment of three. Data are expressed as means $\pm \mathrm{SE} .{ }^{*} P<0.05$.

further evidenced by a higher percentage of cells in the G0-G1 phase and decreasing numbers in the S and G2M phase (Table I).

Recombinant CCN3 was previously reported to induce cell growth reduction [FukunagaKalabis et al., 2006]. To determine whether the inhibition of proliferation was dependent upon the concentration of native CCN3, we tested conditioned media. G59 and G540 cells were incubated for $48 \mathrm{~h}$ in the presence of either fresh medium, or conditioned medium obtained from G540 cells grown for 240 and $312 \mathrm{~h}$. Both cell lines showed a significant decrease in proliferative capability (Fig. 3A). The rate of inhibition observed with the $312 \mathrm{~h}$ conditioned medium was slightly greater than that induced by the $240 \mathrm{~h}$ conditioned medium, suggesting that active CCN3 accumulated in the cell

TABLE I. Cell Cycle Distribution of G59 and G540 Cells Taken at Saturated Density of the Growth Curves

\begin{tabular}{lrr}
\hline & \multicolumn{1}{c}{ G59 } & \multicolumn{1}{c}{ G540 } \\
\hline Sub-G0 & $0.25 \pm 0.07$ & $1.75 \pm 0.07^{*}$ \\
G0-G1 & $62.15 \pm 0.92$ & $71.50 \pm 0.14^{*}$ \\
S & $17.05 \pm 0.64$ & $10.25 \pm 0.21^{*}$ \\
G2M & $24.45 \pm 0.21$ & $18.3 \pm 0.08^{*}$ \\
\hline$* P<0.05$. & &
\end{tabular}

culture medium. Conditioned medium from the G59 cells had no effect on proliferation (data not shown).

Through the use of siRNA we demonstrated that the inhibition of CCN3 synthesis resulted in an abrogation of the growth inhibitory effect attributed to CCN3 in chronic myeloid leukemia cell lines and melanocytes [McCallum et al., 2006; Fukunaga-Kalabis et al., 2006]. As a first step to determine whether the secreted CCN3 protein was indeed responsible for the growth inhibition effect on glioma cells, anti-CCN3 antibodies were added to the culture medium in which the cells were reseeded. While the addition of anti-CCN3 antibodies did not affect G59 growth in normal medium, a slight increase in cell number was observed when G540 cells were incubated in normal medium supplemented with anti-CCN3 antibodies (Fig. 3B, left panel). This moderate relief of growth inhibition might result from two opposite effects: (i) the documented partial neutralization of CCN3 activity by the CT-specific antibodies [Kyurkchiev et al., 2004], and (ii) the accumulation of inhibitory CCN3 protein that was expressed by G540 cells during the $48 \mathrm{~h}$ culture after replating in fresh medium. A similar increase of cell number (18\%) was observed when G59 and G540 cells were grown 


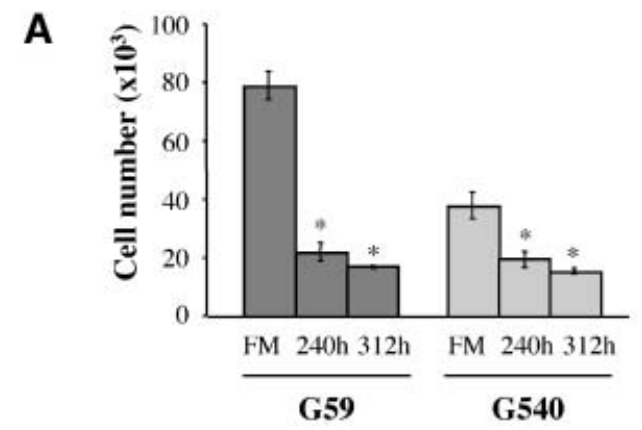

B
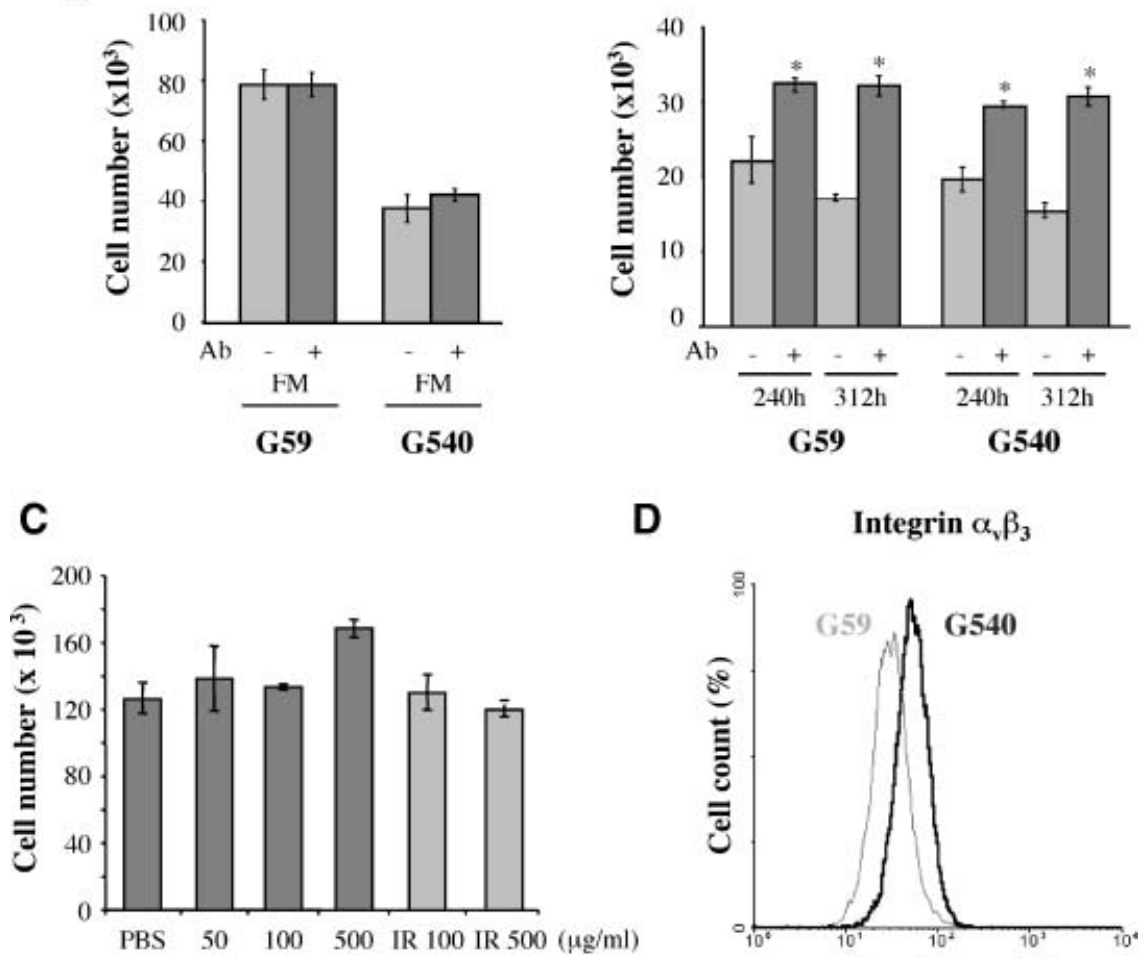

D

Integrin $\alpha_{v} \beta_{3}$

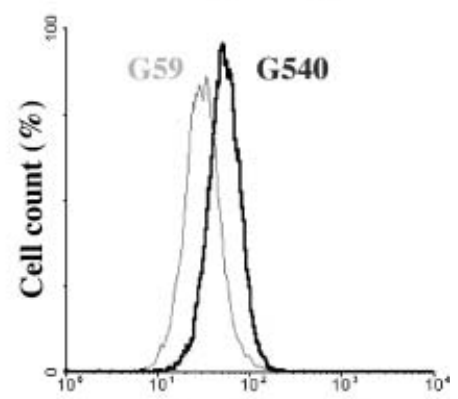

AlexaFluor 488

Fig. 3. The native secreted $\mathrm{CCN} 3$ protein reduces cell proliferation. A: To analyze the effects of secreted CCN3 on cell proliferation, conditioned medium from G540 cells taken at 240 and $312 \mathrm{~h}$ was centrifuged, dialyzed against DMEM, filtered, and supplemented with FCS. G59 and G540 cells were seeded at $2 \times 10^{4}$ cells in 24-well plates and incubated with the conditioned medium (from G540 taken at 240 and $312 \mathrm{~h}$ ) for 48 h. Fresh medium was also used as control (FM). B: Neutralization of CCN3 activity was performed by plating $2 \times 10^{4} \mathrm{G} 59$ and G540 cells in 24-well plates and incubating for 2 days with $500 \mu \mathrm{g} / \mathrm{ml}$ of purified $\mathrm{K} 19 \mathrm{M}$ antibody (Ab) in fresh

in the presence of both conditioned media (240 and $312 \mathrm{~h}$ ) supplemented with anti-CCN3 antibodies (Fig. 3B, right panel). These results indicated that the inhibitory effect of CCN3 might be partially overcome by the anti CCN3specific antibodies. Both cell lines responded in the same way, indicating that inhibition of cell medium (FM) (left panel) or in conditioned medium from G540 taken at 240 and $312 \mathrm{~h}$ (right panel). Data are expressed as means \pm SE. ${ }^{*} P<0.05$. C: $5 \times 10^{3}$ G540 cells were seeded in $24-$ well plates and incubated for 5 days with $50-500 \mu \mathrm{g} / \mathrm{ml}$ of the purified K19M antibody or $100-500 \mu \mathrm{g} / \mathrm{ml}$ of an anti-glycosylated BSA (irrelevant antibody: IR) produced in rabbit. D: Cytofluorometric analysis of integrin $\alpha_{v} \beta_{3}$ expression. Gray line represents G59 cells and black line G540 cells stained with the anti-integrin $\alpha_{v} \beta_{3}$ antibody. The ordinate represents the number of cells.

growth involved similar mechanisms in both cases. Since we had previously established that anti-CCN3 antibodies did not recognize efficiently the native CCN3 protein [Kyurkchiev et al., 2004], only partial restoration of cell growth is observed. Incubation of cells in the presence of antibodies raised against 
glycosylated BSA had no effect on their growth rate (Fig. 3C).

The reduction in cell number induced by incubation in CCN3-containing medium was not the result of a decrease in cell attachment as estimated by cell count numbers of attached cells a few hours after seeding. In addition, G59 cells that expressed CCN3 showed a higher expression of integrin $\alpha_{\mathrm{v}} \beta_{3}$ (Fig. 3D) that was reported to interact with $\mathrm{CCN} 3$ and mediate cell adhesion [Lin et al., 2003, 2005].

\section{The Production of CCN3 is Dependent Upon Cell Density}

Previous results obtained with chicken embryo fibroblasts indicated that the expression of CCN3 mRNA was increased when cells reached saturation density [Scholz et al.,
1996]. Analysis of CCN3 mRNA expression in cultured G540 cells and normal human skin fibroblasts here confirmed that CCN3 mRNA expression increases with degree of confluence of the cells in a time-dependent manner (Fig. 4A).

Based on the analysis of growth curves for G59 and G540 cells, we could draw that the inhibitory effect of CCN3 increased with the number of cells. Since the culture medium was changed every other day, the greater inhibition observed at later time could not be due to an accumulation of CCN3 in the medium. Therefore, we hypothesized that a larger amount of CCN3 protein was produced per cell at higher densities, hence the greater effect upon cell proliferation. Western blotting performed on cell lysates and conditioned medium at several
A

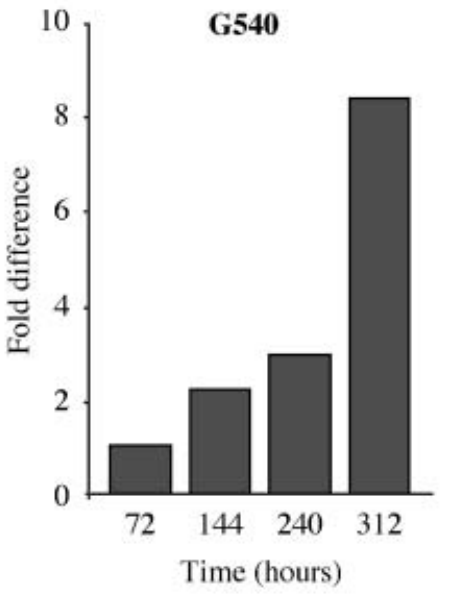

Fibroblasts

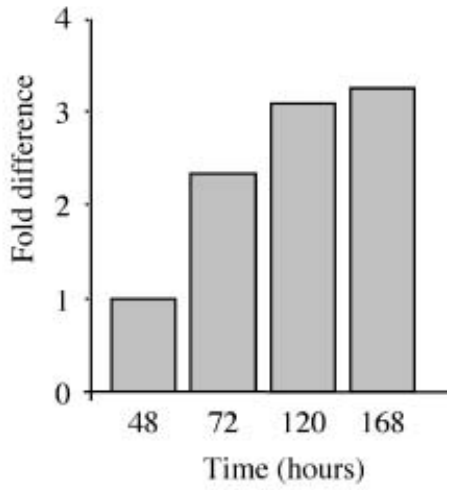

B

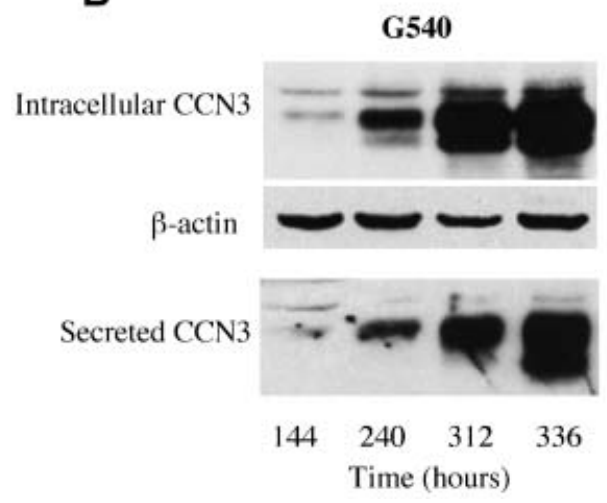

\section{CCN3 protein}

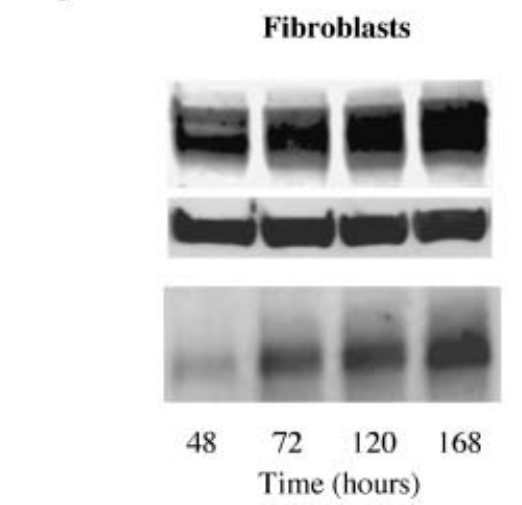

Fig. 4. CCN3 expression increases with time of culture. A: Left panel: CCN3 mRNA analysis CCN3 by RT-PCR in G540 cells harvested at 72, 144, 240, and 312 h. Right panel: CCN3 mRNA analysis CCN3 by RT-PCR in normal human fibroblasts. Cells were collected at 48, 72, 120, and $168 \mathrm{~h}$. In all cases, levels of the housekeeping gene 36B4 were used as an internal control B: Western blot analysis of intracellular and secreted CCN3 protein from G540 cells collected at 144, 240, 312, and $336 \mathrm{~h}$ (left panel) and in normal human fibroblasts collected at 48, 72, 120 , and $168 \mathrm{~h}$ (right panel). $\beta$-actin was used as the loading control. 
points during cell growth indicated that the cellular production of CCN3 and secretion into the cell culture medium increase with cell number (Fig. 4B). We previously reported that secretion of CCN3 occurs rapidly after its production in the cells [Chevalier et al., 1998]. The present results indicated that the increased intracellular concentration did not result from an alteration of the secretion processes.

To determine whether the production of CCN3 was dependent upon cell density, G540 cells were collected after $192 \mathrm{~h}$ of growth, at a stage where they have reached a density of $8 \times 10^{4}$ cells $/ \mathrm{cm}^{2}$, trypsinized and seeded in three different-size plates to obtain cell densities of $1 \times 10^{4}, 8 \times 10^{4}$, and $30 \times 10^{4}$ cells $/ \mathrm{cm}^{2}$ (Fig. 5A). A measurement of the amount of CCN3 produced per cell was performed by Western blotting. The results showed that the amount of CCN3 expressed per cell was dependent upon cell density, the higher production being observed at high cell density (Fig. 5B).

\section{CCN3 Interferes With Cell Cycle Progression and Accumulates at the G2/M Transition}

No major difference in the distribution of cells among the different phases of the cell cycle was observed in actively growing of G59 and G540 cells (data not shown and [Gupta et al., 2001]). However, FACS analysis established that a relatively high proportion of G540 cells at saturated density were in the sub-G0 state (Table I), suggesting that the high production of CCN3 was associated to apoptotic events as suggested for CCN1 and CCN3 [Todorovicc et al., 2005; McCallum et al., 2006]. In agreement with G540 cells undergoing apoptosis, cells taken at $312 \mathrm{~h}$ were unable to attach and grow as compared to G59 cells $(P<0.05)$ (Fig. 6A). Increased apoptosis and cell cycle arrest in G540 cells reaching confluence was confirmed by increased amounts of cytochrome $\mathrm{C}$ and higher levels of the cyclin-dependent kinase inhibitor p21 (Fig. 6B).

We used several inhibitors known to act at various points in the cell cycle to synchronize

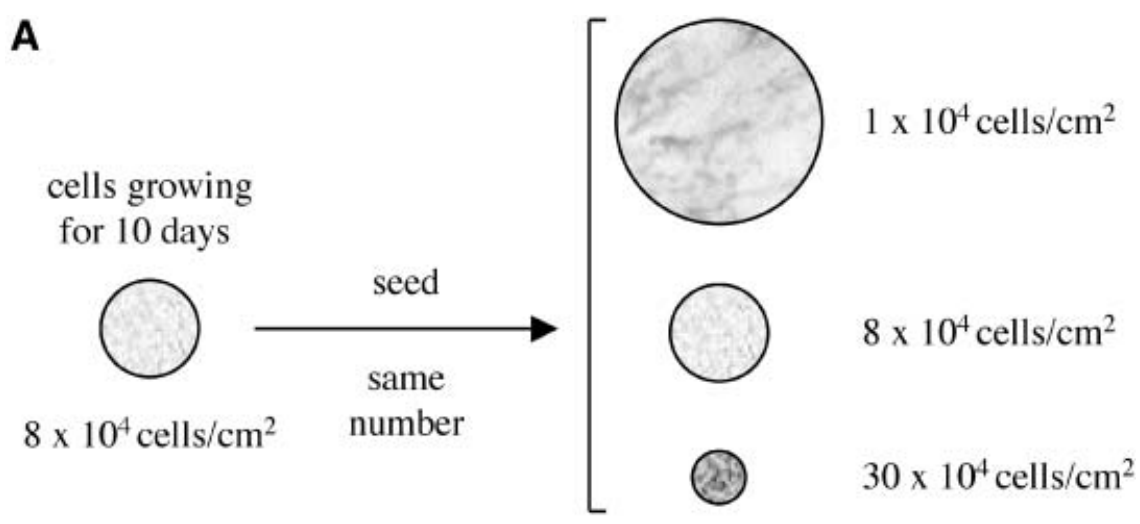

B

Intracellular $\mathrm{CCN} 3$

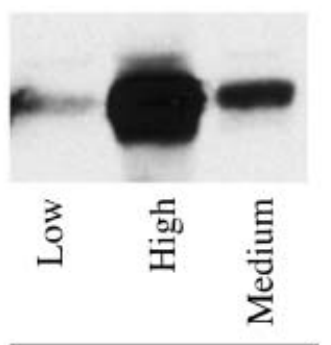

Cell density

Fig. 5. CCN3 expression increases with confluence of the cells. A: Summary of the conditions used for cell seeding. B: Western blot analysis of intracellular CCN3 protein: G540 cells were collected at $192 \mathrm{~h}$ and seeded into Petri dishes of various sizes in order to provide different cell densities. 
A

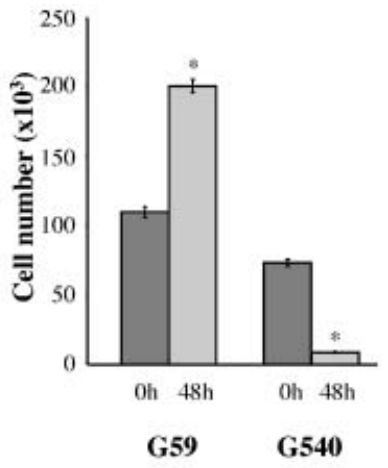

B

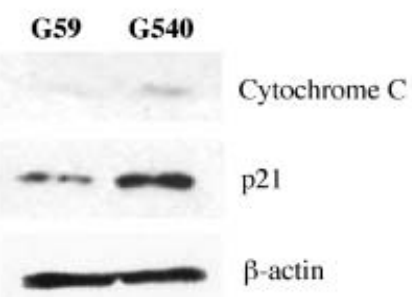

C

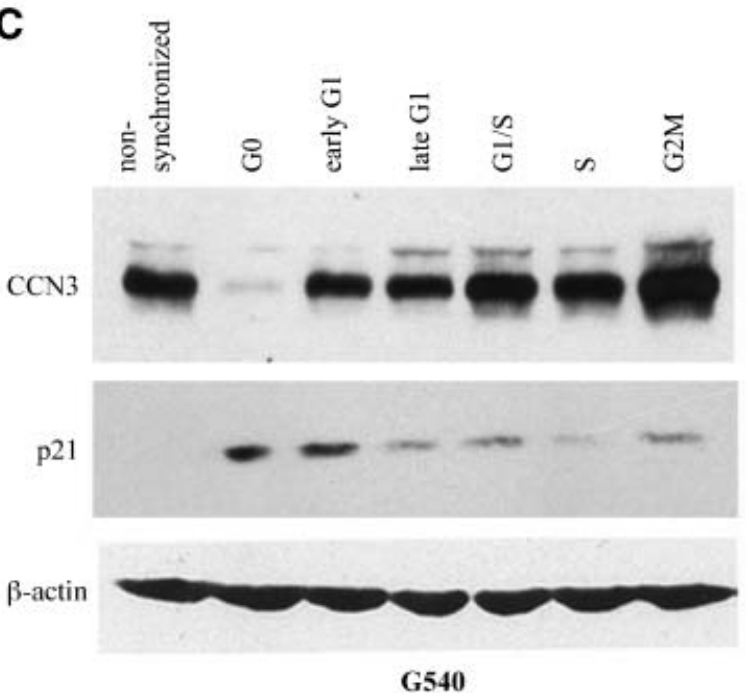

Fig. 6. CCN3 accumulates in the G2/M phase of the cell cycle. A: Cells were collected at $312 \mathrm{~h}$, trypsinized, reseeded in large Petri dishes and counts were performed after $48 \mathrm{~h}$. Data are expressed as means \pm SE. ${ }^{*} P<0.05$. B: Western blot analysis of p21 and cytochrome C in G59 compared to G540 cells. C: Western blot analysis of CCN3 and p21 expression after arrest in each phase of the cell cycle. G540 cells were blocked in (1) G0 phase by serum starvation for $48 \mathrm{~h},(2)$ in early G1 phase after refeeding for $6 \mathrm{~h}$ with complete medium, (3) in late G1 phase after refeeding for $24 \mathrm{~h}$ with medium containing $200 \mu \mathrm{M}$ mimosin, (4) in G1/S phase after refeeding for $24 \mathrm{~h}$ with medium containing $2 \mu \mathrm{g} / \mathrm{ml}$ of aphidicolin, (5) in S phase by washing off aphidicolin for $5 \mathrm{~h}$, and in the G2/M phase $30 \mathrm{~h}$ after refeeding with medium containing $0.1 \mu \mathrm{g} / \mathrm{ml}$ of nocodazole. $\beta$-actin was used as the loading control.
G59 and G540 cells. When cells were synchronized after release from an aphidicolin block, a differential distribution of cells was observed by FACS analysis in CCN3-positive and negative cells (Table II). Whereas $17 \%$ and about $60 \%$ of G59 cells were detected at the S and G2 phase $9 \mathrm{~h}$ after the aphidicolin wash, $43 \%$ and about $29 \%$ of cells were at the S and G2 phase in the G540 culture. The same type of distribution was observed at $12 \mathrm{~h}$ and tends to disappear with time, as cell growth becomes asynchronous. This observation suggested that the decrease in cell proliferation resulted from delayed cell cycle progression mostly at the G2/M transition.

Analysis of CCN3 production during the cell cycle was possible through several means. Serum starvation was used to induce a block at G0. Refeeding for $6 \mathrm{~h}$ with complete medium resets the cells at early G1. A late G1 arrest was obtained with the use of mimosin while a G1/S arrest was induced by incubation with aphidicolin. Washing off aphidicolin permitted to reset the cells at the $\mathrm{S}$ phase. Block at G2/M was induced $30 \mathrm{~h}$ after refeeding the cells with a medium containing nocodazole. At each stage, FACS analysis confirmed that cells were blocked at the expected phase of the cycle, and the quantity of CCN3 expressed by cells was measured by western blotting. While low levels of CCN3 were produced by cells at the G0 phase, the quantity of CCN3 produced gradually increased during $\mathrm{G} 1$ and $\mathrm{S}$ phase to reach a maximum at the G2/M transition (Fig. 6C).

In agreement with the higher percentage of CCN3-expressing cells at the S phase of the cell cycle, a significantly increased expression of MCM6 and MCM3 genes was detected by gene microarray analysis (not shown) and qRT-PCR (Fig. 7A) in the G59 cells stably expressing the

TABLE II. Kinetic of Cell Cycle Distribution After Synchronization of the Cells in G0/G1 With Aphidicolin

\begin{tabular}{|c|c|c|c|c|c|}
\hline & \multirow[b]{2}{*}{ Aphidicolin } & \multicolumn{4}{|c|}{ Wash off aphidicolin } \\
\hline & & $6 \mathrm{~h}$ & $9 \mathrm{~h}$ & $12 \mathrm{~h}$ & $24 \mathrm{~h}$ \\
\hline \multicolumn{6}{|l|}{ G59 } \\
\hline Sub-G0 & $2.4 \%$ & $0.6 \%$ & $0.2 \%$ & $0.4 \%$ & $1.3 \%$ \\
\hline G0-G1 & $74 \%$ & $26.0 \%$ & $22.8 \%$ & $29.3 \%$ & $61.8 \%$ \\
\hline $\mathrm{S}$ & $9.1 \%$ & $49.2 \%$ & $17.0 \%$ & $9.2 \%$ & $18.0 \%$ \\
\hline G2M & $14.5 \%$ & $23.6 \%$ & $\mathbf{5 9 . 7 \%}$ & $60.9 \%$ & $19.0 \%$ \\
\hline \multicolumn{6}{|l|}{ G540 } \\
\hline Sub-G0 & $3.6 \%$ & $0.6 \%$ & $1.1 \%$ & $1.3 \%$ & $4.4 \%$ \\
\hline G0-G1 & $67.7 \%$ & $31.4 \%$ & $27.9 \%$ & $27.3 \%$ & $53.0 \%$ \\
\hline $\mathrm{S}$ & $12.3 \%$ & $52.3 \%$ & $43.0 \%$ & $21.7 \%$ & $17.8 \%$ \\
\hline G2M & $16.5 \%$ & $15.2 \%$ & $\mathbf{2 8 . 6} \%$ & $50.1 \%$ & $25.0 \%$ \\
\hline
\end{tabular}





B


full-length secreted CCN3 protein (pCMV47). Interestingly, the use of two vectors driving the expression of amino-truncated secreted recombinant CCN3 (PNH35 and PNH45) did not result in an increased expression of MCM genes (Fig. 7B), whereas they indeed induced a reduction of cell proliferation similar to the one observed with full-length CCN3 protein (see below). These observations indicated that the induction of MCM genes was not directly related to the antiproliferative activity of CCN3 but reflected instead the higher percentage of cells that remained in the $\mathrm{S}$ phase of the cell cycle.

\section{Proteolysis Accounts for Regulated CCN3 Production}

Because proteasome-dependent proteolytic degradation of several regulatory proteins occurs during cell cycle progression, we compared the levels of CCN3 produced by G540 cells in the presence and in the absence of proteasome inhibitors.

For this purpose, G540 cells were incubated in the presence of MG132 (Z-Leu-Leu-Leu-al) and LLnL (N-acety-L-leucinyl-L-leucinyl-norleucinal) proteasome inhibitors for 6 and $24 \mathrm{~h}$, and the amount of CCN3 produced during these two periods of time was measured both in cell lysates and in conditioned medium. As shown in Figure 8A, incubation in the presence of proteasome inhibitors resulted in a dramatic increase of CCN3 production.

Similarly, when cells plated at low, medium, and high densities were treated by MG132 and LLnL, a considerable increase of CCN3 was observed (Fig. 8B). Furthermore, the amounts of CCN3 produced in these conditions were identical, whereas, in the absence of inhibitors, CCN3 production had been found to be cell density-dependent.

Fig. 7. Expression of MCM genes is increased in glioma cells following expression of CCN3. MCM mRNA relative expression was evaluated by quantitative real-time RT-PCR and expressed as $2^{-\Delta \Delta C T}$. The parental cell line was used as control and calibrator $\left(2^{-\Delta \Delta C \mathrm{C}}=1\right)$. Results represent the mean $\pm \mathrm{SE}$ of duplicate experiments. A: Induction of MCM genes in cells transfected with a plasmid expressing full-length CCN3 (pCMV47). B: CCN3 recombinant proteins lacking one or two amino-terminal modules ( $\mathrm{PNH} 35$ and $\mathrm{PNH} 45$ respectively) do not induce MCM genes expression. G59-pcDNA6: G59 cells stably transfected with pcDNA; G59-pCMV47, G59-PNH35 and G59-PNH45: cells stably transfected with a pcDNA plasmid expressing either the full-length $\mathrm{CCN} 3$ or amino-truncated forms of $\mathrm{CCN} 3$. 


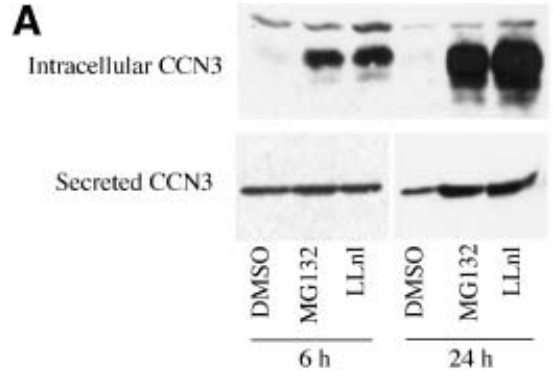

B

$\mathrm{CCN} 3$

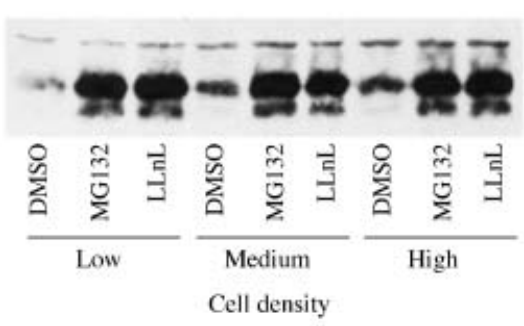

C



$\mathrm{CCN} 3$

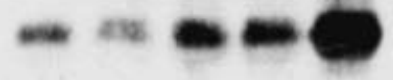

DMSO

$\mathrm{CCN} 3$

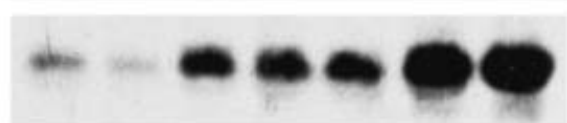

MG132

$\beta$-actin



Fig. 8. Post-translational control of $\mathrm{CCN} 3$ production. A: Western blot analysis of intracellular and secreted CCN3 protein after exposure to proteasome inhibitors: G540 cells were treated with $10 \mu \mathrm{M} \mathrm{MG} 132,100 \mu \mathrm{M} \mathrm{LLnL}$ or solvent DMSO for 6 or 24 h. B: G540 cells were seeded at $1 \times 10^{5}$ (low), $6 \times 10^{5}$ (medium), and $1 \times 10^{6}$ (high cell density) in a 6 -well plates and incubated for $6 \mathrm{~h}$ in the presence of MG132 or DMSO as control. Intracellular $\mathrm{CCN} 3$ expression was analyzed by Western blotting. C: G540 cells were arrested in each phase of the cell cycle as described in the text, and incubated for $6 \mathrm{~h}$ in the presence of MG132 or of DMSO as control. Intracellular CCN3 was analyzed by Western blotting. $\beta$-actin was used as the loading control.

Likewise, the use of proteasome inhibitors increased the amounts of CCN3 produced at the various phases of the cell cycle (Fig. 8C). In that case, the toxicity of the proteasome inhibitors did not permit to conduct a long term experiment with cells synchronized at G1 and G1/S, hence the relative lower amounts detected at these stages in the presence of MG132. In any case, the use of MG132 indicated that the differential amounts of CCN3 detected at $\mathrm{S}$ and $\mathrm{G} 2 / \mathrm{M}$ could become identical upon inhibition of proteasome-associated proteolysis.

These results indicated that in addition to the transcriptional control of CCN3 expression that occurs in the context of cell density, post-translational proteolytic degradation through the proteasome system was responsible for the regulation of CCN3 production by G59 cells and accumulation of CCN3 in confluent cells.

\section{The CT Module is Sufficient to Mediate an Anti-Proliferative Effect}

As the K19M antibody that can partially counteract the antiproliferative activity of CCN3 is directed against the $\mathrm{N}$-terminal sequence of the CT module, we hypothesized that the carboxy-terminal domain of CCN3 might be responsible for the negative effect on cell proliferation.

As a first step to test this hypothesis, we isolated stable clones, following transfection of G59 cells with expression plasmids that carried truncated versions of the cen3 gene. The CCN3 mutants lacking either module 1 (PNH35) or both modules 1 and 2 (PNH45) showed the same antiproliferative activity as the full-length CCN3 protein (G540 and pCMV47), as demonstrated by the growth rate of the stable clones PNH45 and PNH35 (Fig. 9A).

To identify what part of CCN3 was responsible for the inhibitory effect on cell growth, we used several sources of purified and recombinant proteins. Addition of GST-NH5 (containing the CT module of CCN3 fused to GST) to the culture medium of G59 cells resulted in a marked decrease in their proliferation $(24.5 \%$ of growth inhibition compared to GST alone), though less than GST-CCN3 (44\% of inhibition) (Fig. 9B). In order to eliminate the possibility that the GST moiety of the fusion proteins could be involved in the inhibitory effect, the CT domain of GST-NH5 was cleaved with thrombin (Thr-NH5) and purified by immuno-affinity chromatography. Incubating G59 cells in the presence of Thr-NH5 resulted in $80.5 \%$ of growth inhibition compared to control (addition of PBS only). In parallel, we also used an immuno-affinity-purified NH5 protein isolated from yeast culture medium. As shown in Figure 9B, both sources of CT domain (ThrNH5 and Yeast-NH5) showed a strong inhibitory effect on G59 glioma cell growth $(80.5 \%$ and about $55 \%$, respectively), confirming that 

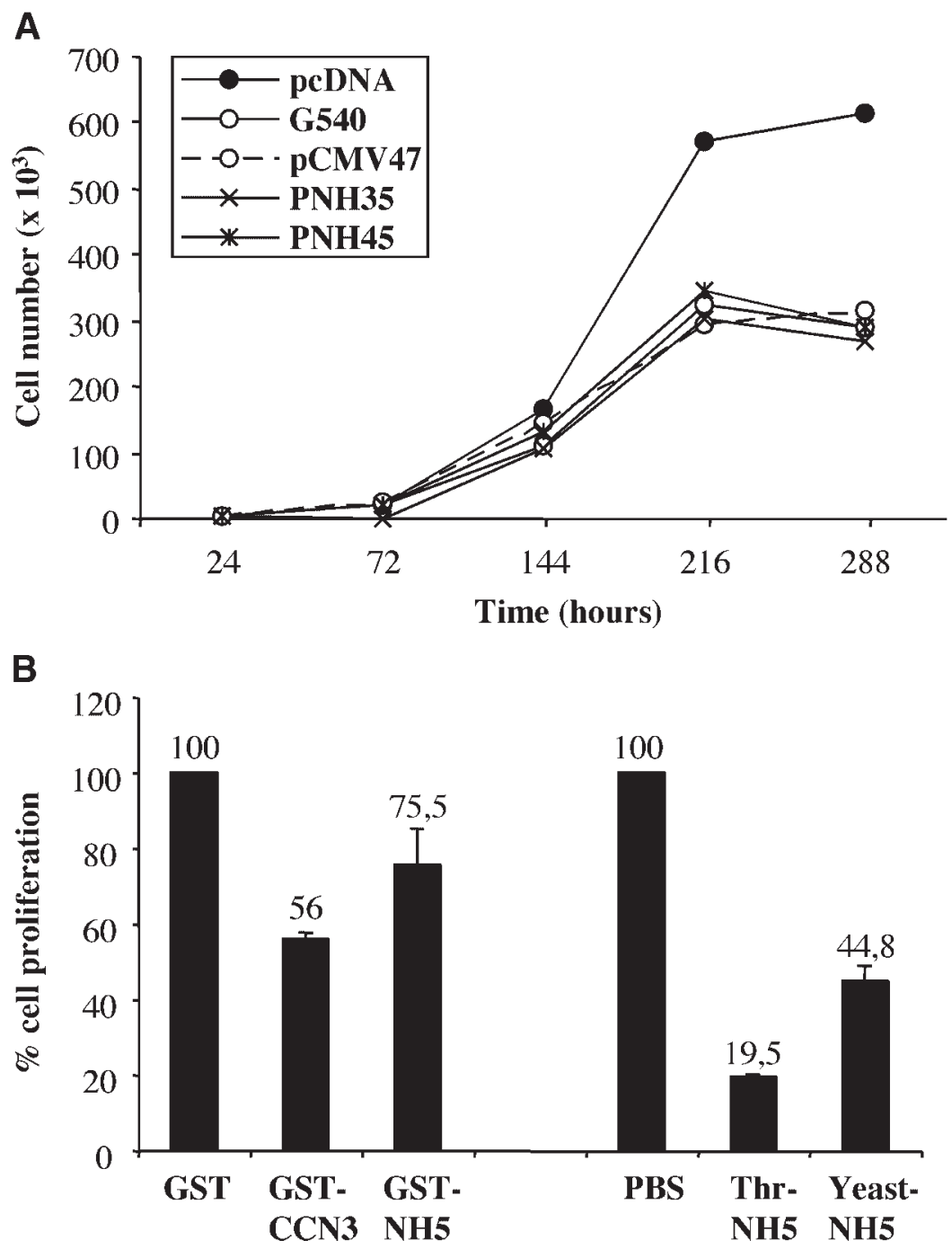

Fig. 9. The CT module is sufficient to induce reduction of cell proliferation. A: Growth curves of G59 stable clones expressing various full-length (G540 and pCMV47) and amino-truncated forms (PNH35 and PNH45) of CCN3 protein. G59 cells stably transfected with pcDNA were used as control. $5 \times 10^{3}$ cells were plated in 24-well plates and the cells were counted at the indicated time points $(24-288$ h). B: Proliferative effect of exogenously added CCN3 proteins on G59 cells. G59 cells

sequences contained in this domain conferred the antiproliferative activity on the full-length protein. The other three modules produced either in bacteria or yeast had no obvious effect on G59 cell proliferation (not shown).

\section{DISCUSSION}

There is strong evidence that CCN3 acts as a negative regulator of cell growth in tumor cells [Gupta et al., 2001; Gellhaus et al., 2004; Benini et al., 2005; Bleau et al., 2005; Planque et al., $\left(5 \times 10^{3}\right)$ were seeded in 24-well plates and incubated with GST, GST-CCN3 fusion proteins or GST-NH5. Similar experiment with either recombinant $\mathrm{NH} 5$ protein that has previously been released from the GST fusion by thrombin cleavage (Thr-NH5) or recombinant $\mathrm{NH} 5$ produced in yeast (Yeast-NH5). These two sources of $\mathrm{NH} 5$ have been purified by immuno-affinity chromatography.

2005; Fukunaga-Kalabis et al., 2006; McCallum et al., 2006]. The first indication of an antiproliferative effect of CCN3 was obtained with glioma cells where the ectopic expression of CCN3 was reported to confer on transfected cells both a reduced growth rate and a decreased tumorigenicity [Gupta et al., 2001]. However, these studies could not discriminate whether or not the inhibitory effects of CCN3 had any incidence on cell cycle progression. Additional data obtained with Ewing's and choriocarcinomas tumor cells confirmed that expression of 
CCN3 was associated with inhibition of proliferation [Gellhaus et al., 2004; Benini et al., 2005]. Recent data showed that CCN3 also reduces proliferation of normal cells [Fukunaga-Kalabis et al., 2006]. These observations are well in line with previous data showing increased expression of CCN3 during the developmental differentiation of several tissues [Katsube et al., 2001; Kocialkowski et al., 2001; Perbal, 2001] and heterotypic differentiation of blastemal cells in Wilms' tumors [Chevalier et al., 1998]. However, they also raise questions regarding the processes that allow CCN3-producing cells to grow quite well in culture and to proliferate within tissues in vivo.

In order to decipher the molecular bases for a controlled production of CCN3 we used our glioma cell model [Gupta et al., 2001] to study the production of $\mathrm{CCN} 3$ at the mRNA and protein levels at various stages of cell proliferation. Our results confirmed that CCN3 protein was indeed responsible for cell growth inhibition. Interestingly, cells that produced CCN3 were responsive to the secreted as well as to the purified recombinant protein, therefore indicating that post-translational modification of CCN3, such as glycosylation and phosphorylation that were previously described [Chevalier et al., 1998; McCallum et al., 2006], were not required for growth inhibition. They also suggested that CCN3-induced inhibition of cell growth was an autocrine-type of response.

While CCN3 produced a dose-dependent inhibitory effect on proliferation rate of G540 cells the degree of inhibition did not exceed 50\% even when increasing amounts of purified CCN3 proteins were added to the cell culture medium. This suggests that CCN3 would inhibit cell proliferation through a rate-limiting step wherein a component is at low concentration under the assay conditions that we used. At this stage we cannot exclude the possibility that post-translational modifications could play a role in modulating the antiproliferative activity of CCN3.

It was of particular interest to observe that the amount of CCN3 protein produced per cell is dependent upon cell density and phase of the cell cycle. The inhibition of cell growth by CCN3 coupled to the increasing production of CCN3 with cell density offers a comprehensive explanation for the lower number of cells at the plateau phase that was observed with
CCN3-producing cells compared to the nonproducing parental cells. An opposite relationship was observed for CCN2 (CTGF) mRNA in bovine aorta endothelial (BAE) cells: a positive signal was detected in sparse, actively growing cultures, while expression was low in confluent quiescent cells. Upon removal of half the quiescent cells, CCN2 protein production increased in cells undergoing active proliferation or migration [Shimo et al., 1998]. These observations suggested that CCN proteins might compete for binding sites and that their relative concentration is a critical determinant of the biological outcome.

In this study we also report that the regulation of CCN3 expression takes place both at the transcriptional and post-transcriptional levels. As previously reported for chicken embryo fibroblasts [Scholz et al., 1996], the quantity of ccn3 mRNA expressed in cultured cells increased at confluence. At the same time, large quantities of CCN3 were secreted into the medium, as a result of a decrease in the proteolytic degradation of CCN3 that occurred during the exponential phase of growth through the proteasome pathway. The proteasome system was reported to play an important role in cell cycle regulation, cell growth, and differentiation [Dalton, 2004]. It is responsible for the degradation of the majority of cellular proteins, cell-cycle regulators, signaling molecules, tumor suppressors, transcription factors, and antiapoptotic proteins [Dou et al., 2003]. Control of mRNA decay by the proteasome pathway has also been reported [Laroia et al., 1999, 2002]. Incubation of G540 cells in the presence of proteasome inhibitors for extended periods of time, also results in an accumulation of ccn3 mRNA (data not shown). It will be interesting to determine whether these effects result from a modification of ccn 3 mRNA halflife or whether they are a consequence of the cytotoxic effects of the inhibitors over long incubation time. It is tempting to propose that proteolytic degradation could provide an additional means to control the production of CCN3 so as to ensure that its inhibitory effect does not interfere with proliferation at early stages of development, when expansion of specific CCN3producing cells is needed.

The increased production of CCN3 during the G2 phase of the cell cycle points to a direct role for CCN3 in the reorganization of the cytoskeleton and shed new light on the interactive 
networks that are involved in feedback between gap junctions, adherent junctions, and cytoskeleton [Giepmans, 2006].

The CT module of CCN3 clearly stands as an essential and sufficient domain for the antiproliferative activity of this protein. This is consistent with the well-documented participation of this module in the physical interaction of CCN3 with key partners in the regulation of cell proliferation [Perbal et al., 1999; Sakamoto et al., 2002; Lombet et al., 2003; Fu et al., 2004; Gellhaus et al., 2004; Bleau et al., 2005; Planque et al., 2005; Perbal, 2006; Perbal and Planque, 2006; Planque, 2006]. The CT module is represented in five of the six CCN proteins that constitute the CCN family of proteins. This C-terminal module contains six cystein residues that are predicted to be engaged in three interlaced disulphide bonds that form a cystine knot [Perbal and Planque, 2006]. A host of proteins contains CT modules with cystine knots. Crystal structures of transforming growth factor beta (TGF $\beta$ ), nerve growth factor, platelet-derived growth factor (PDGF), and human chorionic gonadotropin (HCG) all indicated that the active forms of these proteins are either homo- or heterodimers, the formation of which requires the interactions of cystine knot motif. The presence of such a motif in a large number of biologically relevant proteins raises the fascinating possibility that heterodimers may form between several of these proteins and may govern complex biological functions. In light of this model, the involvement of the CT domain in the antiproliferative activity of this protein suggests that physical partners of CCN3 may act in concert with this protein in regulating of cell proliferation. We have already established that the CT module of CCN3 is involved in the physical interaction with fibulin 1C, Notch1 and Connexin 43 [Perbal et al., 1999; Sakamoto et al., 2002; Fu et al., 2004; Gellhaus et al., 2004]. We believe that the CT domain also permits heterodimerization of different CCN proteins and that the formation of heterodimers might play a critical role in regulating the negative biological activity of CCN3. Our present study established that recombinant CCN3 proteins lacking the amino-proximal modules could still inhibit cell growth. Whether the CT module also plays a similar function in other CCN proteins remains an open question.

The ongoing characterization of proteins that physically interact with the CT domain of CCN3 is aimed at this important question. It will also be critical to establish whether the negative activity conferred by the CT module is modulated by other constitutive modules of CCN3. Once the nature of the residues responsible for the antiproliferative activity of the CT module of CCN3 is confirmed, this will hopefully open the way to the use CCN3-derived synthetic peptides as new tools in molecular medicine.

\section{ACKNOWLEDGMENTS}

This work was supported by the Ministère de l'Education Nationale, de l'Enseignement Supérieur et de la Recherche, and by the European Commission (grant number: PROTHETS LSHC-CT-2004-5030306). Dr. A.M. Bleau was supported by the Fonds de la Recherche en Santé du Québec. Dr. N. Lazar is supported by the European PROTHETS grant. The technical help of M. Grospierre is acknowledged. Dr P. Martin (Université de Nice, France) is acknowledged for providing the $\mathrm{BBg}$ vector. Thanks are due to C. Jaulin, M. LeRigoleur, O. Julienne, M. Bessedic, and G. Briet for their support, and to A. Perbal for her help.

\section{REFERENCES}

Benini S, Perbal B, Zambelli D, Colombo MP, Manara MC, Serra M, Parenza M, Martinez V, Picci P, Scotlandi K. 2005. In Ewing's sarcoma CCN3 (NOV) inhibits proliferation while promoting migration and invasion of the same cell type. Oncogene 24:4349-4361.

Bleau AM, Planque N, Perbal B. 2005. CCN proteins and cancer: Two to tango. Front Biosci 10:998-1009.

Bork P. 1993. The modular architecture of a new family of growth regulators related to connective tissue growth factor. FEBS Lett 327:125-130.

Brigstock DR. 2003. The CCN family: A new stimulus package. J Endocrinol 178:169-175.

Chevalier G, Yeger H, Martinerie C, Laurent M, Alami J, Schofield P, Perbal B. 1998. novH: Differential expression in developing kidney and Wilms' tumours. Am J Pathol 152:1563-1575.

Dalton WS. 2004. The proteasome. Semin Oncol 6(Suppl 16):3-9.

Dou QP, Smith DM, Daniel KG, Kazi A. 2003. Interruption of tumor cell cycle progression through proteasome inhibition: Implications for cancer therapy. Prog Cell Cycle Res 5:441-446.

Fu CT, Bechberger JF, Ozog MA, Perbal B, Naus CC. 2004. CCN3 (NOV) interacts with connexin43 in C6 glioma cells: Possible mechanism of connexin-mediated growth suppression. J Biol Chem 279:36943-36950.

Fukunaga-Kalabis M, Martinez G, Liu ZJ, Kalabis J, Mrass P, Weninger W, Firth SM, Planque N, Perbal B, Herlyn M. 2006. CCN3 controls 3D spatial localization of 
melanocytes in the human skin through DDR1. J Cell Biol 175:563-569.

Gellhaus A, Dong X, Propson S, Maass K, Klein-Hitpass L, Kibschull M, Traub O, Willecke K, Perbal B, Lye SJ, Winterhager E. 2004. Connexin43 interacts with NOV: A possible mechanism for negative regulation of cell growth in choriocarcinoma cells. J Biol Chem 279: 36931-36942.

Giepmans BN. 2006. Role of connexin43-interacting proteins at gap junctions. Adv Cardiol 42:41-56.

Gupta N, Wang H, McLeod TL, Naus CC, Kyurkchiev S, Advani S, Yu J, Perbal B, Weichselbaum RR. 2001. Inhibition of glioma cell growth and tumourigenic potential by CCN3 (NOV). Mol Pathol 54:293-299.

Joliot V, Martinerie C, Dambrine G, Plassiart G, Brisac M, Crochet J, Perbal B. 1992. Proviral rearrangements and overexpression of a new cellular gene (nov) in myeloblastosis-associated virus type 1-induced nephroblastomas. Mol Cell Biol 12:10-21.

Katsube K, Chuai ML, Liu YC, Kabasawa Y, Takagi M, Perbal B, Sakamoto K. 2001. The expression of chicken NOV, a member of the CCN gene family, in early stage development. Brain Res Gene Expr Patterns $1: 61-65$.

Kocialkowski S, Yeger H, Kingdom J, Perbal B, Schofield PN. 2001. Expression of the human NOV gene in first trimester fetal tissues. Anat Embryol 203:417-427.

Kyurkchiev S, Yeger H, Bleau AM, Perbal B. 2004. Potential cellular conformations of the CCN3 (NOV) protein. Cell Commun Signal 2:9.

Laroia G, Cuesta R, Brewer G, Schneider RJ. 1999. Control of mRNA decay by heat shock-ubiquitin-proteasome pathway. Science 284:499-502.

Laroia G, Sarkar B, Schneider RJ. 2002. Ubiquitindependent mechanism regulates rapid turnover of AUrich cytokine mRNAs. Proc Natl Acad Sci USA 99:18421846.

Lau LF, Lam SC. 1999. The CCN family of angiogenic regulators: The integrin connection. Exp Cell Res 248:44-57.

Li WX, Martinerie C, Zumkeller W, Westphal M, Perbal B. 1996. Differential expression of novH and CTGF in human glioma cell lines. Mol Pathol 49:91-97.

Li CL, Martinez V, He B, Lombet A, Perbal B. 2002. A role for CCN3 (NOV) in calcium signalling. Mol Pathol 55: $250-261$.

Lin CG, Leu SJ, Chen N, Tebeau CM, Lin SX, Yeung CY, Lau LF. 2003. CCN3 (NOV) is a novel angiogenic regulator of the CCN protein family. J Biol Chem 278: 24200-24208.

Lin CG, Chen CC, Leu SJ, Grzeszkiewicz TM, Lau LF. 2005. Integrin-dependent functions of the angiogenic inducer NOV (CCN3): Implication in wound healing. J Biol Chem 280:8229-8237.

Lombet A, Planque N, Bleau AM, Li CL, Perbal B. 2003. CCN3 and calcium signalling. Cell Commun Signal 1:1.

McCallum L, Price S, Planque N, Perbal B, Pierce A, Whetton AD, Irvine AE. 2006. A novel mechanism for BCR-ABL action: Stimulated secretion of CCN3 is involved in growth and differentiation regulation. Blood 108:1716-1723.

Perbal B. 2001. NOV (nephroblastoma overexpressed) and the CCN family of genes: Structural and functional issues. Mol Pathol 54:57-79.
Perbal B. 2003. The CCN3 (NOV) cell growth regulator: A new tool for molecular medicine. Expert Rev Mol Diagn 3 : 597-604.

Perbal B. 2004. CCN proteins: Multifunctional signalling regulators. Lancet 363:62-64.

Perbal B. 2006. New insight into CCN3 interactionsnuclear CCN3: Fact or fantasy? Cell Comm Signal 4:6.

Perbal B, Planque N. 2006. CCN3. AfCS-Nature Molecule Pages (doi:10.1038/mp.a003943.01). The AfCS-Nature Signaling Gateway. http://www.signaling-gateway.org/.

Perbal B, Takigawa M. 2005. The CCN family of proteins: An overview. In: Perbal B, Takigawa M, editors. The CCN proteins: A new family of cell growth and differentiation regulators. London: Imperial College Press. pp 1-18.

Perbal B, Martinerie C, Sainson R, Werner M, He B, Roizman B. 1999. The C-terminal domain of the regulatory protein $\mathrm{NOVH}$ is sufficient to promote interaction with fibulin 1C: A clue for a role of NOVH in celladhesion signaling. Proc Natl Acad Sci USA 96:869874.

Planque N. 2006. Nuclear trafficking of secreted factors and cell-surface receptors: New pathways to regulate cell proliferation and differentiation, and involvement in cancers. Cell Commun Signal 4:7.

Planque N, Perbal B. 2003. The CCN proteins, a new family of cell growth regulators. In: Pandalai SG, editor. Recent research developments in human pathology, Vol. 1. 2003 Part II. Trivandrum: Transworld Research Network. pp 333-369.

Planque N, Bleau AM, Perbal B. 2005. The CCN3 protein: A multifunctional cell growth regulator. In: Perbal B, Takigawa M, editors. The CCN proteins: A new family of cell growth and differentiation regulators. London: Imperial College Press. pp 239-257.

Planque N, Li CL, Saule S, Bleau AM, Perbal B. 2006. Nuclear addressing provides a clue for the transforming activity of amino-truncated CCN3 proteins. J Cell Biochem 99:105-116.

Quan T, He T, Voorhees JJ, Fisher GJ. 2005. Ultraviolet irradiation induces Smad7 via induction of transcription factor AP-1 in human skin fibroblasts. J Biol Chem 280 : 8079-8085.

Rachfal AW, Brigstock DR. 2005. Structural and functional properties of CCN proteins. Vitam Horm 70:69-103.

Sakamoto K, Yamaguchi S, Ando R, Miyawaki A, Kabasawa Y, Takagi M, Li CL, Perbal B, Katsube K. 2002. The nephroblastoma overexpressed gene (NOV/ccn3) protein associates with Notch1 extracellular domain and inhibits myoblast differentiation via Notch signaling pathway. J Biol Chem 277:29399-29405.

Scholz G, Martinerie C, Perbal B, Hanafusa H. 1996. Transcriptional down-regulation of the nov proto-oncogene in fibroblasts transformed by p60v-src. Mol Cell Biol 16:481-486.

Shimo T, Nakanishi T, Kimura Y, Nishida T, Ishizeki K, Matsumura T, Takigawa M. 1998. Inhibition of endogenous expression of connective tissue growth factor by its antisense oligonucleotide and antisense RNA suppresses proliferation and migration of vascular endothelial cells. J Biochem 124:130-140.

Todorovicc V, Chen CC, Hay N, Lau LF. 2005. The matrix protein CCN1 (CYR61) induces apoptosis in fibroblasts. J Cell Biol 171:559-568. 